\title{
PRZEDSIĘBIORSTWO I JEGO OTOCZENIE W OBLICZU CZWARTEJ REWOLUCJI PRZEMYSLOWEJ - WYZWANIA, SZANSE I ZAGROŻENIA
}

DOI: 10.33141/po.2020.01.01

\section{Elżbieta Mączyńska, Ewa Okoń-Horodyńska}

\section{Wprowadzenie}

U powszechniła się argumentacja, iż współczesna gospodarka doświadcza tzw. czwartej rewolucji przemysłowej (4RP), egzemplifikowanej głównie poprzez Przemysł 4.0 (Schwab, 2015; Sustainability, 2018). Właściwie, w swych podstawach, Przemysł 4.0 (Industrie 4.0 - I4.0) nie jest związany ani $\mathrm{z}$ rozwojem nowej technologii, ani $\mathrm{z}$ nowym modelem biznesowym w przemyśle. Jest to krok w przód w kierunku digitalizacji, mechatronizacji produkcji (Olszewski, 2016), połączony z nowym podejściem do osiągania wyników (wartości dodanej), które jeszcze dekadę temu były niemożliwe do zrealizowania. Różni się on tym od wersji poprzedniej, że łącząc istniejące technologie równocześnie zaciera granice między sferami fizyczną, cyfrową i biologiczną procesów wytwórczych i prowadzi do nieznanego. Dla opisania tego zjawiska stosuje się więc też wiele innych określeń, jak rewolucja informacyjna, informatyczna, cyfrowa, digitalna, cywilizacja wiedzy, gospodarka 4.0 itp., próbując znaleźć adekwatne odniesienie do zmian o nieznanym dotąd dynamizmie, ale też chaosie, które $\mathrm{w}$ istocie zamknąć należałoby w pojęciu przesilenia cywilizacyjnego (Kleer, 2016). Oznacza ono sytuację, kiedy jedna cywilizacja się kurczy i wypierana jest przez nową, stanowi więc jakiś wciąż niedodefiniowany wzorzec poprzemysłowy gospodarki i społeczeństwa, w którym większość technologii, które zdominują funkcjonowanie gospodarki i społeczeństwa za 30 lat, nie została jeszcze wynaleziona, a do końca XXI wieku 70\% dzisiejszych zawodów zostanie zastąpionych przez automatyzację/ robotyzację (Kelly, 2018). Nadzwyczaj szybkie tempo pojawiania się nowych technologii wyprzedza możliwości wcześniejszego przygotowania się na zmiany zarówno producentów i konsumentów, jak i mechanizmów regulacji stanowiących ich instytucjonalne otoczenie. Dochodzi więc do zjawiska blokady, zamknięcia w „starych” ramach systemowych uniemożliwiających otwarcie się na nowe wyzwania podmiotów gospodarczych, w tym głównie przedsiębiorstw. Chaotyczność i przypadkowość formułowania warunków instytucjonalnych coraz trudniej wpisuje się $\mathrm{w}$ realizację uzupełniających rynek funkcji państwa jako regulatora zjawisk społeczno-gospodarczych, wykazując często jego słabość we wspieraniu, a także ochronie interesów przedsiębiorstw zmuszonych przez globalne wyzwania rynkowe do podejmowania prób szukania przewag konkurencyjnych w nośnikach czwartej rewolucji przemysłowej. I właśnie wokół tego problemu skoncentrowane są przedstawione w niniejszym artykule refleksje. 
Celem analitycznym jest tu wskazanie na główne trendy w gospodarce kształtujące się w wyniku czwartej rewolucji przemysłowej oraz identyfikacja niezbędnych kierunków zmian $\mathrm{w}$ zarządzaniu przedsiębiorstwami i funkcjonowaniu ich otoczenia instytucjonalnego określającego reguły, wpływającego na możliwości rozwoju, kreującego szanse, ale i bariery, a nawet zagrożenia. Stawia się tezę, iż otwarcie gospodarki na potencjał czwartej rewolucji przemysłowej staje się niezbędnym warunkiem utrzymania zdolności do rynkowego konkurowania oraz sprostania nowym, choć niezmiennie ukierunkowanym efektywnościowo wymogom rynku. Zarazem czwarta rewolucja przemysłowa wymusza zmianę modeli funkcjonowania biznesu, co przejściowo, jak wykazuje praktyka, prowadzi do rozmaitych asymetrii i niedostosowań społeczno-gospodarczych, zarządczych oraz regulacyjnych. Asymetrie te uwidaczniają się m.in. na rynku pracy czy $\mathrm{w}$ instrumentarium fiskalnym.

Wskazuje się też na luki badawcze wymagające głębszych dociekań, co do możliwości sprostania nowym warunkom związanymi $z$ fenomenalnymi przemianami technologicznymi, jak np. konieczność uwzględnienia nowej filozofii proinkluzywnego wzorca kształtowania rzeczywistości społeczno-gospodarczej, nowych wzorców zarządzania (Micklethwait, Wooldridge, 2000). Chodzi więc o włączenie przedsiębiorstw do łagodzenia tych asymetrii i realizacji celu, jakim jest potrójnie zrównoważony (Kołodko, 2014) rozwój inkluzywny, nauczenie się godzenia $\mathrm{w}$ procesie zarządzania celów społecznych, gospodarczych, technologicznych i ekologicznych przy równoczesnym ograniczaniu do minimum marnotrawstwa zasobów materialnych i ludzkich oraz zmniejszaniu rozpiętości między rzeczywistym a potencjalnym poziomem produktywności. Na zasadność podejmowania tej tematyki wskazuje m.in. narastające ryzyko zagrożeń wynikających z coraz wyraźniejszego, zwłaszcza w rozwiniętych gospodarkach Zachodu, syndromu sekularnej stagnacji (Summers, 2014, s. 27-41), która dotknąć może wszystkich wpadających w pułapkę opóźnień czasowych.

Podstawą przedstawionych w tym opracowaniu analiz jest polska i zagraniczna literatura przedmiotu. Zawarte tu oceny i wnioski w znacznej mierze oparte są na hermeneutyce. Ponadto mają one podłoże w analizach danych statystycznych ${ }^{1}$ oraz przeprowadzonych dotąd badaniach obcych i własnych ${ }^{2}$. Identyfikowane wyzwania i zagrożenia wskazują na konieczność redefinicji zawartości otoczenia przedsiębiorstwa oraz budowania nowych wzorców modeli biznesowych i formuł zarządzania $\mathrm{w}$ przedsiębiorstwie zdolnych do sprostania wyzwaniom różnych form przejawiania się 4RP. W opracowaniu sygnalizuje się trzy wątki: pierwszy odnosi się do teoretycznych podstaw kształtowania się zrębów otoczenia przedsiębiorstwa, konieczności jego ewolucji w nowych warunkach technologiczno-społecznych; drugi dotyczy podstawowego warunku dynamizmu 4RP, jakim jest cyfryzacja i adekwatność jej postępów do wyzwań, zaś w trzecim wątku podjęto dyskusję i ocenę gotowości do wdrożenia Przemysłu 4.0.

\section{Relacje państwa i rynku w warunkach czwartej rewolucji przemysłowej - interpretacyjne meandry a konsekwencje dla kształtowania otoczenia instytucjonalnego przedsiębiorstwa}

$J$ edną z najbardziej kontrowersyjnych kwestii także w warunkach technologicznej rewolucji współczesnej gospodarki jest rola państwa, w tym relacje między państwem a rynkiem, stanowiące swoiste otoczenie bliższe i dalsze warunkujące działalność przedsiębiorstw, warunki ich rozwoju, wywołujące zagrożenia, ale też kreujące nowe szanse. Jak wiadomo, w teoretycznej analizie roli państwa w gospodarce rynkowej wyróżnia się dwa główne nurty: liberalny i interwencjonistyczny. W pierwszym postuluje się ograniczenie roli państwa w gospodarce do niezbędnego minimum, jak zapewnienie obrony narodowej i swobody działania społeczeństwu, pilnowanie porządku i ładu publicznego poprzez tworzenie infrastruktury instytucjonalnej zapewniającej niczym nieskrępowane działanie sił rynkowych. Rynek, jako najdoskonalszy i samoczynnie działający mechanizm alokacyjny $\mathrm{w}$ gospodarce, umożliwia tu efektywne i pełne wykorzystanie czynników produkcji oraz realizuje ekonomiczne oczekiwania, nie wywołując konfliktów, a więc najlepiej rozwiązuje wszelkie problemy gospodarcze (Owsiak, 2017). Wielki kryzys lat trzydziestych XX w. nie potwierdził tej tezy, wymuszając niejako narodzenie się nurtu interwencjonistycznego jako antytezy na niedoskonałości rynku skutkujące zarówno brakiem stabilizacji, jak i nieracjonalnością alokacji zasobów oraz dystrybucji dochodów. Konieczność aktywnego uczestnictwa państwa w rozwiązywaniu problemów niedoskonałości rynku zawarta w koncepcji J.M. Keynesa uznawana jest za przełom w teorii ekonomii (Markowski, 1992, s. 20-21). I choć keynesizm nie jest nurtem jednorodnym (np. neokeynesizm czy postkeynesizm), stanowi teoretyczne uzasadnienie interwencjonizmu państwowego aż do początków lat siedemdziesiątych XX w., kiedy to niekorzystne zjawiska w gospodarce kapitalistycznej, takie jak nasilenie inflacji, wzrost deficytu budżetowego, długu publicznego, osłabienie tempa wzrostu gospodarczego, podważyły podstawy teorii J.M. Keynesa. Na powrót uznania nabrały poglądy wyrastające $\mathrm{z}$ doktryn wolności gospodarczej zwane neoliberalizmem, choć w różnych odsłonach (m.in. monetaryzm, nowa ekonomia klasyczna, ekonomiczna teoria polityki, ekonomia podażowa), wyrażające wiarę w skuteczność mechanizmu rynkowego i niechęć do aktywnej roli państwa w gospodarce, promujące „deregulację”, wykazując wyższość niedoskonałych rynków nad niedoskonałymi rządami, co znalazło szeroki odzew w dyskusjach publikacyjnych (Wojtyna, 1997). W okresie reaganomiki i thatcheryzmu teza państwa minimum była silnie forsowana (Reagan, 2012) i zdecydowanie umocowana w kształtowaniu polityki społeczno-gospodarczej wielu krajów, wyznaczając tym samym „reguły gry” dla przedsiębiorstwa. Niestety, w wyniku ułomnych interpretacji dzieł A. Smitha w praktyce dochodziło m.in. do ścierania 
się rozmaitych interesów, w tym zwłaszcza preferencji wielkich, ponadnarodowych korporacji i powstawania strat ekonomicznych i społecznych na skutek nieadekwatnych do potrzeb regulacji działania biznesu (Mączyńska, 2017). Wbrew poglądom A. Smitha przypisano mu sformułowanie tezy o minimalistycznym państwie w roli „stróża nocnego", co jest interpretacyjnym nadużyciem, bo pochodzi ono od niemieckiego socjalisty Ferdinanda Lassallea (1862). Takiemu pojmowaniu roli państwa przeczy wiele tez A. Smitha, w których wyrażał niejako społeczną wrażliwość, sugerując konieczność aktywnej roli państwa w kształtowaniu porządku społeczno-gospodarczego. „Sprawiedliwość (...) jest główną kolumną, która podtrzymuje cały gmach. Jeśli się ją usunie, wielka, potężna struktura społeczności ludzkiej, ta struktura, której wzniesienie i podtrzymanie zdaje się być w tym świecie, jeśli mogę tak powiedzieć, szczególną i ukochaną troską Natury, musi wkrótce rozsypać się na małe cząsteczki” (Smith, 1989, s. 127).

Warto zauważyć, iż forsowanie w minionych kilku dekadach przez wiele krajów neoliberalnych koncepcji państwa-minimum stanowiło podstawę zwolnienia państwa z odpowiedzialności za społeczno-gospodarcze dysfunkcje gospodarki rynkowej, co miało także konsekwencje w tworzeniu warunków dla rozwoju przedsiębiorstw. Brak podstaw do wskazanej interpretacji zależności państwa i rynku unaoczniły skutki światowego kryzysu finansowego pierwszej dekady XXI w. czy też obserwowane od wielu lat w gospodarce globalnej groźne wynaturzenia, między innymi: skrajnie asymetryczny rozkład światowego bogactwa i nasilanie się nierówności społecznych, trudności w przeprowadzeniu niezbędnych zmian strukturalnych gospodarki, zwiększanie się asymetrii informacyjnej, w sposób szczególny deformującej bazę dla podejmowania decyzji dotyczących strategii rozwoju przedsiębiorstw, wykształcanie się różnego rodzaju pułapek (np. średniego dochodu, średniego produktu, braku równowagi, pułapki demograficznej, instytucjonalnej, kompetencji cyfrowych). W rozwiązanie tych problemów nie włączały się przedsiębiorstwa, bowiem rynek tego nie wymagał, a państwo nie motywowało, stąd nawarstwianie problemów regulacyjno-aktywizujących się potęgowało. W wyniku wysoce asymetrycznego podziału światowego bogactwa dynamizujący się we współczesnej gospodarce postęp technologiczny nie przekłada się w dostatecznym stopniu na poprawę jakości życia ludzi. Nawet w materialnie zasobnych krajach i społecznościach nasilają się negatywne procesy społeczne, takie jak dehumanizacja, pogarszające się relacje społeczne, terroryzm, erozja demokracji i inne (Rifkin 2011, Mazzucatto, 2016; Wallerstein i in., 2016; Kołodko 2010), decydujące przecież o kształtowaniu się postaw biznesowych, relacji biznesu z pracownikami czy szerzej - otoczenia dla biznesu. Temu niebezpiecznemu zjawisku przypisuje się wręcz cechy bomby z opóźnionym zapłonem. I jest ono od lat jednym ze stałych tematów corocznego Światowego Forum Ekonomicznego w Davos.

Poszukiwanie rozwiązań dla wyżej omówionych problemów wskazuje na wielość składających się na taki stan czynników. Podstawową rolę odgrywa tu jednak z pewnością synergiczny charakter sprzężeń pomiędzy motywacją i charakterem przemian technologicznych kształtowanych przez 4RP a ramami ustrojowymi wyznaczającymi sposób funkcjonowania państwa jako kreatora otoczenia instytucjonalnego dla funkcjonowania przedsiębiorstw. W tym przypadku bowiem zaangażowanie państwa wydaje się kluczowym czynnikiem umożliwiającym rozwój w sposób pełny i kompleksowy Przemysłu 4.0. Jak pokazuje niemieckie doświadczenie, I4.0 to nie jakieś pojedyncze działanie konkretnego przedsiębiorstwa, ale cała strategia rozwoju gospodarki, społeczeństwa i działających w niej przedsiębiorstw, bazująca na możliwości tworzenia dynamicznych, samoorganizujących się, międzyorganizacyjnych sieci, które można zoptymalizować według wybranych kryteriów przedstawiających $\mathrm{w}$ istocie połączenie pracy ludzi i systemów informatycznych (Bitkom, 2016). Ostatecznie bowiem strategia I4.0 odnosi się do sposobu organizacji i kontroli strumienia wartości w cyklu życia produktu i powinna zawierać wielowymiarowe instrumentarium państwa, pozwalające na przesuwanie się kraju (a więc i przedsiębiorstw) w górę w globalnym łańcuchu wartości dodanej (GVC). Rola państwa w kwestii dotyczącej przygotowania się do wyzwań I4.0 musi łączyć kilka wątków. Z jednej strony rzecz dotyczy przełamania słabości państwa w zwalczaniu zawodności rynku, blokujących uruchomienie pełnego potencjału gospodarczego (Banse i in., 2019, s. 50-56, 110-118). Z drugiej zaś strony chodzi o stworzenie adekwatnej do wyzwań polityki innowacyjnej wykazującej skuteczność zarządzania państwa wywołującego przekierowanie gospodarki w stronę Przemysłu 4.0, w tworzenie otoczenia (ładu) instytucjonalnego zachęcającego do aktywności inwestycyjnej w rozwiązania technologiczne (głównie cyfrowe), formułującego skuteczne instrumenty motywacji (finansowe, organizacyjne, kadrowe, społeczne) do podejmowania ryzyka - wraz z państwem - w proces transformacji przemysłu i społeczeństwa. Trzeba więc chyba mówić o nowej polityce innowacyjnej państwa, której logika musi opierać się na koordynacji i synergii takich bloków, jak: edukacja wykorzystująca wiele źródeł powstawania wiedzy (przedsiębiorstwa, laboratoria, międzynarodowe praktyki, wspólne warsztaty, projekty, itp.), koordynacja działania biznesu i nauki w zakresie potrzeb doskonałości kształcenia, badań i produkcji, koordynacja odbiorców i producentów (popytowe innowacje), współdziałanie producentów $\mathrm{z}$ organizacjami rynku pracy - prowadzenie monitoringu potrzeb kwalifikacyjnych i „wypadających” z rynku zawodów, wielowymiarowe narzędzia zróżnicowanego, jednak znacznego wsparcia finansowego dla innowatorów, rozwój zamówień publicznych na innowacje, prowadzenie ciągłych badań foresightowych w zakresie kształtowania się trendów technologicznych i społecznych w danej gospodarce, troska o bezpieczeństwo technologiczne i ekonomiczne w danej gospodarce (Okoń-Horodyńska, 2018).

Podjęcie wskazanych aktywności przez politykę innowacyjną państwa umożliwi przedsiębiorcom słabiej zaangażowanym $\mathrm{w}$ postępującą reidustrializację i marginalizujących znaczenie niskich kosztów siły roboczej dostosowanie się do realiów 4RP, wymagającej wysokich nakładów, których wykorzystanie musi być sieciowo ko- 
ordynowane, aby minimalizować marnotrastwo (Buhr, Stehnken, 2018, rozdz. 3). Utrzymywanie strategii budowania przewagi konkurencyjnej na niskich kosztach pracy i opóźnieniach czasowych w reindustrializacji grozi spychaniem przedsiębiorstw i krajów do lokalizacji w najprostszych elementach globalnych łańcuchów wartości, a więc grozi tzw. ryzykiem spirali marginalizacji (Boston Consulting Group, 2016, s. 19-22). Szczególna rola państwa w rzeczywistości 4RP wiąże się z koniecznością tworzenia i wykorzystania narzędzi minimalizowania polaryzacji między pracownikami wysoko wykwalifikowanymi, pożądanymi przez I4.0, a pracownikami o niskich kwalifikacjach, których praca może być w coraz większej skali zastępowana przez automatyzację, stąd popyt na nich będzie maleć, a zagrożenia w postaci nierówności społecznych będą rosnąć. Szczególnie, iż coraz bardziej widoczna też będzie rosnąca skala korzyści osiąganych $\mathrm{z}$ innowacji przez dostawców kapitału, głównie intelektualnego, ale też inwestycyjnego i wszelkich jego współudziałowców (Schwab, 2015). Prezentowane głosy w dyskusji pozwalają na wykazanie, iż rozważania dotyczące relacji państwo-rynek stanowią płaszczyznę oceny zdolności otoczenia przedsiębiorstwa do zmotywowania decyzji o podjęciu wyzwań czwartej rewolucji przemysłowej.

\section{Transformacja cyfrowa - warunek dynamizmu czwartej rewolucji przemysłowej}

$\mathbf{P}$ rzełomowy charakter przemian eliminujących jeden porządek przez inny (Kleer, 2016, s. 52) wywoływany jest przede wszystkim przez transformację cyfrową. Traktowanie bowiem wiedzy - najcenniejszego dobra, jakim dysponuje ludzkość, jako czegoś dostępnego dla wszystkich bez żadnych ograniczeń - a o to właśnie tu chodzi - to koncepcja zdecydowanie niepasująca do kapitalistycznego sposobu postrzegania świata. Istotą masowej cyfryzacji informacji - i tym samym ludzkiej wiedzy nie jest bowiem jedynie ułatwienie dostępu do informacji, ale zmiana natury samej informacji, a przede wszystkim dynamika zwiększania ich ilości i zakresu wykorzystania przez podmioty zbiorowe technik informacyjnych i komunikacyjnych (ICT). Informacja traktowana przez stulecia na równi $\mathrm{z}$ innymi dobrami materialnymi, stopniowo stająca się towarem najcenniejszym, może wkrótce przestać być traktowana w ogóle jako coś, co można kupić i sprzedać. O wartości w procesie wytwarzania zaczyna bowiem decydować nie sama możliwość wytworzenia produktu, ale przepis nań, czyli w warunkach 4RP - sterujące jego złożonością i kompleksowością oprogramowanie. Kraje uznawane za posiadające najlepiej rozwinięte systemy gospodarcze zaświadczają, iż to właśnie wiedza i jej twórcy z zapleczem organizacyjnym, doświadczeniem, kompetencjami zawodowymi, zdolnością do współpracy z klientami, czyli kapitał intelektualny (Edvinsson, Malone, 2001), stanowią motor postępu ekonomicznego, zapewniający tworzenie i utrzymanie owych „przepisów”, które reszta świata jedynie wykonuje. W koncepcji I4.0 ta właśnie idea jest zachowana i to w skali dotąd najwyżej rozpoznanej, w konsekwencji wszechobecności digitalizacji - w przetwórstwie, środowisku biznesowym, relacjach pracowników $\mathrm{z}$ maszynami, kształtowaniu łańcucha wartości itp. (Lasi i in., 2014). Dzięki digitalizacji I4.0 staje się koncepcją, która obiecuje większą elastyczność produkcji, masową personalizację, zwiększoną prędkość, integrację i zdolność dostosowawczą, niskie bariery wejścia do procesu produkcji partnerskiej dzięki sieciowości, lepszą jakość i wydajność, niższe koszty, zoptymalizowanie, precyzję, synergię współdziałania człowieka z maszyną. Przemysł 4.0 staje się więc zorientowany na usługi i interoperacyjny proces produkcji, który jest powiązany $\mathrm{z}$ algorytmami, dużymi zbiorami danych i zaawansowanymi technologiami (Lu, 2017), zapewniającymi nieznaną dotąd szybkość dotarcia do rynku, co jest też najważniejszym źródłem przewagi konkurencyjnej. Dlatego wiele miejsca w badaniu efektywności gospodarek poświęca się ocenie stopnia ich cyfryzacji jako potencjalnego źródła nowych możliwości rozwoju przedsiębiorstw. Na przykład z Raportu ITU (2018) wynika, iż na koniec 2018 roku 51,2\% populacji świata (3,9 mld ludzi) korzystało z Internetu. W krajach rozwiniętych 4/5 funkcjonowało on line, w krajach rozwijających się było to $47 \%$ populacji, ale w 47 najsłabiej rozwiniętych krajach świata 4/5 (80\%) populacji nie ma wciąż dostępu do Internetu. Prawie cała światowa populacja ma dostęp do sieci telefonii komórkowej, większość korzysta $\mathrm{z}$ Internetu 3G lub wyższej klasy, 3/4 światowej populacji posiadała w 2017 roku telefon komórkowy, 56\% posiadaczy reprezentowało 47 krajów najsłabszych gospodarczo. Dostęp do Internetu w gospodarstwach domowych osiągnął poziom $60 \%$ populacji świata w 2018 roku, w roku 2005 było to $20 \%$ (ITU, 2018, rozdz. 1, s. 2). Niestety, znacznie gorzej wygląda statystyka umiejętności cyfrowych, $1 / 3$ populacji świata posiada bazowe umiejętności, $41 \%$ ludzi posiada umiejętności standardowe (instalowanie, konfigurowanie), a tylko $4 \%$ populacji posiada znajomość specjalistycznych umiejętności, a więc znajomość języka pozwalającego pisać programy komputerowe (ITU, 2018, rozdz. 2).

Jednym z najbardziej znanych mierników oceny efektywności cyfrowej jest udział ICT w gospodarce, mierzony udziałem ICT w PKB oraz w zatrudnieniu, nakładami na $\mathrm{B}+\mathrm{R}$ w ICT, zatrudnieniem pracowników naukowo-badawczych w ICT, ilością komputerów. Od 2006 r. badania wykorzystania ICT we wszystkich krajach UE są prowadzone na podstawie Rozporządzenia nr 808/2004 dotyczącego statystyk Wspólnoty w sprawie społeczeństwa informacyjnego (SI), które ma na celu stworzenie jednolitego systemu międzynarodowej statystyki w tej dziedzinie, aby umożliwić dokonywanie porównań wskaźników charakteryzujących kluczowe obszary wykorzystania ICT $\mathrm{w}$ przedsiębiorstwach, gospodarstwach domowych i przez osoby prywatne w gospodarstwach domowych czy w przedsiębiorstwach, dostępem do sieci szerokopasmowej itp., które to dane publikowane są m.in. przez Eurostat (2019) czy GUS (2019). Dane dotyczące cyfryzacji wprowadzane są zarówno do budowania złożonych wskaźni- 
ków innowacyjności czy konkurencyjności gospodarek (Kowalski, Weresa, 2019, s. 7-13), jak i samej cyfryzacji, jak np. ICT Development Index (IDI, 2019). Analizuje się tu osiągnięcia państw w trzech grupach: gotowość do rozwoju ICT (infrastruktura, dostęp), wykorzystanie ICT oraz umiejętności w dziedzinie ICT, a wskaźnik przybiera wartości od 0 do 10 (IDI, 2019). W rankingu IDI z 2017 roku, w analizie 176 krajów, najlepsza była Islandia $(8,98)$, drugie miejsce zajęła Korea Południowa $(8,85)$, a trzecie Szwajcaria $(8,74)$. Polska zajęła 49 miejsce $(6,89)$ za Białorusią (32), Słowenią, (33), Litwą (35), Republiką Czeską (43), Rosją (45), Słowacją (46), Węgrami (48), (ITU, 2017, s. 1). Metodyka oceny ucyfrowienia gospodarki staje się coraz bardziej złożona, a jednym z zintegrowanych wskaźników opracowanych przez Komisję Europejską jest indeks gospodarki cyfrowej i społeczeństwa cyfrowego (DESI, 2019). Skupia on aż 30 współczynników podzielonych na grupy według takich kryteriów, jak: poziom rozwoju infrastruktury łącznościowej i dostępu do niej, umiejętności cyfrowe kapitału ludzkiego, intensywność wykorzystania Internetu przez społeczeństwo, zakres wdrażania i integrowania technologii cyfrowych przez przedsiębiorstwa oraz poziom cyfrowych usług publicznych, a także badania i rozwój ICT, zaś maksymalna wartość indeksu wynosi 100. W okresie od 2018 do 2019 roku wszystkie kraje UE poprawiły swoją wydajność cyfrową. Finlandia (70), Szwecja, Holandia i Dania (prawie 70) uzyskały najwyższe wartości wskaźnika i należą do światowych liderów cyfryzacji. W dalszej kolejności plasują się Wielka Brytania, Luksemburg, Irlandia, Estonia i Belgia. Jednak niektóre inne kraje wciąż mają przed sobą długą drogę (w tym Polska, zajmująca miejsce 25 na 28 państw, wciąż poniżej średniej unijnej), co oznacza, iż UE jako całość potrzebuje zdecydowanej poprawy, aby móc konkurować na arenie światowej (DESI, 2019, s. 1). Wymagać to jednak będzie zarówno w przedsiębiorstwach, jak i na wyższych poziomach struktury gospodarki znacznych inwestycji w całkowicie nowy sprzęt, w całe systemy ICT, wyedukowania i zatrudnienia specjalistów o nowych kompetencjach (takich jak np. analitycy przetwarzania gigadanych, serwisanci urządzeń mechatronicznych, zarządzający złożonymi i kompleksowymi projektami realizowanymi w sieciach), wysokiego stopnia specjalizacji zawodowej, nowego podejścia do udostępniania i zabezpieczania własności intelektualnej, budowania adekwatnych do zmiennych potrzeb strategii cyfryzacji, tworzenia zindywidualizowanych modeli biznesowych, racjonalnego wykorzystywania standaryzacji w rozwoju innowacji, umiejętnej akceptacji integracji przepływów danych w całym globalnym łańcuchu wartości.

Transformacja cyfrowa $\mathrm{w}$ największym chyba dotąd zakresie egzemplifikuje koncepcję procesu twórczej destrukcji J. Schumpetera (2009, s. 101-102), bowiem dynamika przemian wywołanych przez ICT „wywraca” niejako dotychczasowy porządek teoretyczny, oddziałujący na zarządzanie w przedsiębiorstwie. Obowiązujące przez wiele lat modele równowagowe, będące pewną fotografią optymalnego stanu na rynku czy szerzej: w gospodarce, przestają mieć zastosowanie $\mathrm{w}$ świecie ciągłych zmian.
Technologie cyfrowe ograniczają wady typowych dla cywilizacji industrialnej i dotychczasowych modeli państwa, powiązań wertykalnych, opartych na rozmaitych podległościach instytucjonalnych, w tym biznesowych. $\mathrm{W}$ związku z tym przeciwstawia się wzorzec dotychczas dominującego „kapitalizmu wertykalnego” wzorcowi „kapitalizmu horyzontalnego”. W gospodarce opartej na technologiach cyfrowych coraz bardziej bowiem zacierają się granice między sektorami a instytucjami, co wyzwala korzystne warunki dla transparentności, demokratyzacji życia i relacji społecznych, efektywności (koszty są nieistotne) i szybkości podejmowania decyzji, pozytywnie ukierunkowując tradycyjne otoczenie podmiotów gospodarczych ${ }^{3}$. Transformacja cyfrowa staje się potężnym katalizatorem ludzkiej twórczości, wyzwala rozwój gospodarki współdzielenia, nowe formy finansowania innowacji (np. crowdfunding) i ich tworzenia (standaryzacja), dynamizują się sieci społecznościowe wykorzystywane do współtworzenia towarów i usług, do dzielenia się wiedzą. Problem w tym, iż przemiany wynikające $\mathrm{z}$ transformacji cyfrowej nie wywołują adekwatnych do nich dostosowań instytucjonalnych, pozbawiając państwo, tak istotnej w tych przemianach - siły regulatora. Da się na przykład zauważyć, iż większość instytucjonalnych wysiłków współczesnego państwa (nawet w krajach rozwiniętych) zorientowana jest na budowanie infrastruktury społeczeństwa informacyjnego $\mathrm{w}$ jego klasycznym, czysto kapitalistycznym rozumieniu. Nowe regulacje prawne i infrastruktura techniczna podporządkowane są wspomaganiu tworzenia i dystrybucji wiedzy rozumianej jako cenny towar.

Poza możliwościami regulacyjnymi pozostaje często wiedza i informacja upowszechniana nieodpłatnie, niepodlegająca ograniczeniom prawa własności intelektualnej, często wręcz owe nowe regulacje stanowią balast ograniczający możliwości rozwoju wiedzy i dostępu do informacji (CRN, 2016). Z opóźnieniem wprowadzane są też wszelkie zinstytucjonalizowane formy „wspierania” społeczeństwa informacyjnego, czego dowodem są cytowane, relatywnie niskie wskaźniki społeczeństwa informacyjnego w UE. Następstwem tego działania może być swego rodzaju zjawisko kulturowego zakotwiczenia, negatywnego uzależnienia, zamknięcia - na kształt swoistego lock-in effect - w dotychczasowych (niezmienionych) ramach systemowych $\mathrm{w}$ podejmowaniu strategicznych decyzji o priorytetach, potencjałach, rozwiązaniach i narzędziach, stanowiącego barierę rozwojową gospodarki cyfrowej (Peters, 2010, s. 50 i dalsze). Praktyka potwierdza bowiem, że narzędzia typowe dla cywilizacji industrialnej są nadal stosowane, mimo ich ograniczonej i zmniejszającej się skuteczności, a także rosnącego niebezpieczeństwa stosowanych starych-nowych narzędzi mix "promowania” Przemysłu 4.0 czy podejmowania działań strategicznych $\mathrm{w}$ wyznaczaniu scenariuszy przyszłości (Okoń-Horodyńska, 2018, s. 234-240). Trudno jednak nie zauważyć w dyskusji głosów i takich, iż transformacja cyfrowa leżąca u podstaw przełomów technologicznych w przemyśle zwiększa ryzyko destrukcji w systemie wartości społecznych, czyli 
anomii. Ludzie stworzyli „odhumanizowany 'technopol', w którym klasyczne wartości humanistyczne zostały zagłuszone przez technikę" (Postman, 1992, s. 49-50). Nasilenie anomijne ma obecnie wymiar globalny, a związane z nim zjawiska wynikają w sposób szczególny m.in. $\mathrm{z}$ cech charakteryzujących wolny rynek (Akerlof, Shiller, 2017), gdzie ludzie mają nie tylko pełną swobodę wyboru, lecz także niczym nieograniczoną swobodę „naciągania” innych, a gdzie technologie cyfrowe tworzą szczególne ku temu okazje, tworząc "całkowicie nowe sposoby na to, by kłamać, oszukiwać, okradać i terroryzować” (Kelly, 2018, s. 381), bowiem rynek jest dysfunkcyjny. Wystarczy wskazać m.in. na zjawisko internetowych fake newsów, tj. celowych oszustw i dezinformacji o ludziach, sprawach, produktach, firmach, czy zjawisko internetowego hejtu, czyli przejawów agresji i nienawiści. Na szczęście jednak cyfrowe technologie sprzyjają też wykrywaniu, wizualizacji i nagłaśnianiu rozboju, oszustw oraz manipulacji, doskonaląc warunki przeciwdziałania oszustwom, dezinformacji, wykrywania ludzkich błędów i niebezpieczeństwa.

W warunkach transformacji cyfrowej, a zarazem dysfunkcji rynku, najważniejsze jest zatem, aby potencjał technologii cyfrowych był wykorzystywany w sposób ukierunkowany na poprawę jakości życia ludzi, przyjazne środowisko dla działalności przedsiębiorstw, humanitaryzm i ograniczanie anomijnych destrukcji. Po raz kolejny powtórzyć więc należy, iż niezbywalną rolę ma tu do spełnienia państwo, tym samym konieczne jest poszukanie rozwiązań ukierunkowanych na znalezienie właściwych relacji między funkcjami państwa i rynku w kształtowaniu adekwatnego do wyzwań cyfrowych otoczenia dla przedsiębiorstw. Zdecydowana pomoc w tym zakresie zapewniona być może przez badaczy przedmiotu wyjaśniających, jakie podstawowe gwarancje muszą być zapewnione przez państwo społeczeństwu w zmieniających się dynamicznie warunkach, a więc m.in. gwarancje wysokiej jakości edukacji, usług medycznych, wolności gospodarczej, praworządności oraz dochodów przez całe życie (Wallerstein i in., 2016). Technologie cyfrowe zwiększają siłę jednostek w egzekwowaniu wskazanych gwarancji, umożliwiając każdemu, m.in. poprzez sieci społecznościowe, forsowanie swoich opinii, postulatów i propozycji rozwiązań, weryfikację informacji, dając szansę realizacji rozlicznych interesów społeczno-ekonomicznych. Przykładami takich działań jest uspołecznienie niektórych zasobów, jak edukacji, przestrzegania porządku publicznego czy w dużej mierze dostępu do informacji, umożliwiając rozprzestrzenianie się gospodarki współdzielenia, co nazywane jest wręcz cyfrowym socjalizmem, trzecią drogą, która unieważni wiele dotychczas przyjmowanych prawd (Kelly, 2018, s. 195-202). Transformacja cyfrowa wyzwala na świecie swoisty wyścig o tworzenie optymalnych warunków dynamizujących rozwój I4.0, którego architektami i realizatorami są głównie przedsiębiorstwa, zaś instytucjonalnymi motywatorami bądź „hamulcowymi” państwo i rynek, przy czym na skutek dysfunkcji rynku państwo obciążone jest większymi obowiązkami w tworzeniu przyjaznego dla transformacji cyfrowej otoczenia, podążając w kierunku intensywnie dyskutowanej koncepcji e-państwa, bądź działającego wg reguł biznesowych państwa przedsiębiorczego (Mazzucato, 2016). W sposób szczególny powinno więc ono oddziaływać na:

1) zmniejszenie asymetrii informacyjnej,

2) wspieranie dyfuzji wiedzy,

3) minimalizowanie problemu niekompletności i niedoskonałości rynków,

4) kształtowanie ładu instytucjonalnego dla wszechogarniającej transformacji cyfrowej,

5) zwiększanie puli środków państwa na finansowanie kolejnych generacji innowacji w przedsiębiorstwach, szczególnie w ICT i robotyzację, a także likwidację syndromu prywatyzacji zysków i upubliczniania strat.

\section{Problem gotowości do wdrożenia Przemysłu $4.0 \mathrm{w}$ przedsiębiorstwie i gospodarce}

zwarta rewolucja przemysłowa egzemplifikowana jej głównym filarem, Przemysłem 4.0, urosła do zjawiska, będącego przedmiotem rosnącej ilości badań, ocen czy szerszej dyskusji ${ }^{4}$. Przemysł jako taki wciąż silnie napędza rozwój gospodarki - kreuje 65\% nakładów na $\mathrm{B}+\mathrm{R}$, generuje $80 \%$ innowacji i ponad $50 \%$ europejskiego eksportu (CEU, 2018, s. 2). W ciągu ostatnich kilku lat nastąpił też dynamiczny rozwój europejskich inicjatyw na rzecz wspierania I4.0, a strategie, Platformy I4.0 lub specjalistyczne programy finansowe posiadają już niemal wszystkie państwa najwyżej rozwinięte oraz duża część państw doganiających (KE, 2018). Patrząc na analizy ekonomiczne z poziomu mikro, pierwsze skojarzenia dotyczące Przemysłu 4.0 ukierunkowuje na proces produkcyjny, a tu z kolei na krzywą możliwości produkcyjnych i funkcję produkcji. Kierując się paradygmatem racjonalności, wprowadzanie jakichkolwiek zmian w przedsiębiorstwie ma sens tylko wtedy, jeśli korzyści przewyższają koszty. Wprowadzając kosztowne technologie, należy oczekiwać przede wszystkim wyższego poziomu produkcji przy zwiększonym poziomie efektywności, co oznacza, że 4RP $\mathrm{z}$ istoty swej przesuwa granice możliwości produkcyjnych $\mathrm{w}$ górę. Dysponując takimi samymi zasobami, można osiągać zwiększenie produkcji praktycznie w każdej dziedzinie, a czynnikiem sprawczym jest szerokie zastosowanie technik informacyjnych i rozwiązań związanych z przetwarzaniem i przekazywaniem gromadzonych informacji. Zachodzące $\mathrm{w}$ procesie produkcji zmiany technologiczne mogą mieć dużo dalej idące przełożenie, pod ich wpływem modyfikacji ulegać może bowiem sam kształt funkcji produkcji, która, jak dowodzą badania, przy zmianach o charakterze rewolucyjnym wykazuje początkowo gwałtowny wzrost poziomu produkcji, a następnie jej korzystną stabilizację (Olender-Skorek, 2017, s. 41-42). Przebieg funkcji produkcji może mieć wiele wymiarów, bowiem będzie on wyznaczany przez dodatkowe, poza klasycznymi, czynniki decydujące o znacznej złożoności tej funkcji, o wartościach trudno mierzalnych i dużej dynamice, ale też nadzwyczajnych efektach. Tak więc, $\mathrm{z}$ teoretycznego punktu widzenia oczekiwania dotyczące 
znaczących korzyści ekonomiczno-społecznych możliwych do osiągnięcia w warunkach $4 \mathrm{RP}$ znajdują argumentację. W praktyce wdrożenie I4.0 i utrzymanie jego rosnącej tendencji w gospodarce w największym stopniu dotyczy przedsiębiorstwa, jego zasobów, zarządzania nimi, podejmowania wyzwań i ryzyka $\mathrm{z}$ tym związanego oraz nowych relacji $z$ otoczeniem. W istocie bowiem $\mathrm{I} 4.0$ jest zbiorczym terminem dla technik i zasad funkcjonowania organizacji łańcucha wartości łącznie stosujących lub używających systemów cyberfizycznych, Internetu rzeczy i przetwarzania chmurowego. Jest urzeczywistnieniem inteligentnej fabryki, w której systemy cyberfizyczne sterują procesami fizycznymi, tworzą wirtualne (cyfrowe) kopie świata realnego i podejmują zdecentralizowane decyzje, a poprzez Internet rzeczy w czasie rzeczywistym komunikują się i współpracują ze sobą oraz z ludźmi, natomiast dzięki przetwarzaniu chmurowemu są oferowane i użytkowane usługi wewnętrzne i międzyoperacyjne (DII4.0, 2017; Sustainability, 2018, s. 203).

Proces produkcji staje się mocno elastyczny, co w połączeniu $\mathrm{z}$ automatyzacją umożliwia masową personalizację produkcji, wzrost wydajności i elastyczności asortymentu, ale wymaga odmiennego od dotychczasowego sposobu zarządzania, a otoczenie przedsiębiorstwa jest często trudne do zdefiniowania, jako że wiodące pojęcia tu stosowane to współpraca, integracja, sieci, współdziałanie, współdzielenie, synergia itp., zaś czynniki geopolityczne mają zdecydowanie niknący wpływ. Wdrażanie I4.0 dotyczy nie tylko technologii, ale też nowych sposobów współpracy i roli ludzi $\mathrm{w}$ przemyśle, rozważanych $\mathrm{w}$ różnych aspektach, konfiguracjach i z wielu punktów widzenia, wyznaczając zróżnicowane podejścia w poszczególnych krajach. Przy czym podejście praktyczne wykazują raczej przedsiębiorstwa w gospodarkach wysoko rozwiniętych, zaś na teoretycznych dywagacjach koncentrują się kraje słabsze technologicznie (Banse, 2019, s. 221-305). I tak np. w gospodarce amerykańskiej przeważa optyka praktyczności, uwaga koncentrowana jest na tworzeniu radykalnych innowacji cyfrowych służących transformacji świata fizycznego (renesans przemysłu) i szybkiej realizacji wartości dodanej. Niemiecka (europejska) wersja I4.0 bazuje na doskonałości inżynierskiej w transformacji cyfrowej w celu realizacji wizjonerskich koncepcji integracji wokół gospodarki dobrobytu. Chinom zależy na pragmatycznych rozwiązanych $w$ celu szybkich wygranych $\mathrm{z}$ jednej strony, ale $\mathrm{z}$ drugiej strony na długookresowych strategiach rozwoju kluczowych technologii. Japonia i Korea Płd. koncentrują się na zdolnościach do osiągania skali masowej produkcji $\mathrm{w}$ inteligentnych fabrykach, na silnych technologicznie produktach, na dużych przedsiębiorstwach (ACATECH, 2016). Swoisty „ruch” związany z zainteresowaniem I4.0, który w 2017 roku objął aż 80\% przedsiębiorstw na świecie, uznających I4.0 za szanse rozwoju; w USA - 90\% firm, w gospodarce Niemiec 92\% firm, a w Japonii 78\% firm. Tylko dla 20\% przedsiębiorstw I4.0 nie wzbudzał zainteresowania, traktowano go jako wręcz zagrożenie (McKinsey Digital, 2016). Pojawiła się więc potrzeba rozwijania metodyki oceny gotowości do wdrażania I4.0. Wśród podejść do oceny gotowości gospodarek narodowych i przedsiębiorstw do wdrażania I4.0 znaczące propozycje metodyczne zaproponowało Światowe Forum Ekonomiczne w postaci wskaźnika $R e$ adiness for the Future of Production, a dwa jego główne elementy to: struktura produkcji i czynniki napędzające produkcję - czyli kluczowe czynniki wpływające na wykorzystanie 4RP do transformacji systemów produkcyjnych. Wskaźnik przybiera wartości od 0 do 10 (World Economic Forum, 2018). Z kolei, Duński Instytut Przemysłu opracował we współpracy z naukowcami, urzędnikami i biznesem indeks gotowości do wdrożenia I4.0, składający się z 7 filarów aktywności, odnosi się on do poziomu krajowego (DII4.0, 2017). Wskaźnik gotowości Rolanda Bergera Industry 4.0 Readiness Index przygotowany dla gospodarki UE składa się z dwóch kategorii: „przemysłowej doskonałości," która ocenia złożoność procesu produkcyjnego, stopień automatyzacji, intensywność innowacji, gotowość siły roboczej, i „sieci wartości”, gdzie analizuje się wysokość wartości dodanej, otwartość branży, sieć innowacji, kompleksowość wykorzystania ICT. Indeks wyłania 4 grupy krajów wg skali gotowości do I4.0, takich jak: faworyci, tradycjonaliści, wahający się i potencjaliści (Berger, 2014). Dla przykładu, w 2016 roku niemiecka gospodarka plasowała się na 15 miejscu pod względem cząstkowego wskaźnika gotowości do pracy w sieci - bazy dla rozwoju I4.0, miejsce pierwsze zajmował Singapur; zaś pod względem $R B$ Readiness Industry 4.0 Index należała wraz z Singapurem do faworytów i okazała się liderem w UE (Berger, 2014, s. 16). Według Global Industry 4,0 Readiness Index, Niemcy osiągnęły w 2016 roku miejsce 4 wśród 120 krajów, przed Singapurem, Szwajcarią i Finlandią, Polska była na pozycji 43 (DII4, 2017, s. 20). W obszarze możliwości samodzielnej oceny gotowości przedsiębiorstwa wciąż najbardziej popularny jest model IMPULS (2015), który ocenia dojrzałość przedsiębiorstw produkcyjnych w 6 wymiarach: strategia i organizacja, inteligentna fabryka, inteligentne operacje, inteligentne produkty, usługi danych i pracownicy. Znaczącą aktywność w pracach metodycznych nad oceną gotowości do wdrożenia I4.0 wykazał Singapur, tworząc wskaźnik Smart Industry Readiness Index (SIRI, 2019). Dyrektor zarządzający konsorcjum opracowującym wskaźnik Chng Kai Fong, Managing Director (EDB, 2017, s. 2), stwierdził, iż:

„Wprawdzie zainteresowanie branżą 4.0 wzrosło, ale wiele firm doświadcza obecnie "pułapki pilotażowej”, w której mogą być prowadzone działania transformacyjne, ale muszą one jeszcze wykroczyć poza dowody koncepcji, aby przynieść wymierne korzyści finansowe. Współpraca pozwoli nam stworzyć neutralny, otwarty i wykwalifikowany ekosystem Przemysłu 4.0, który ułatwi transformację procesów, technologii i organizacji w skali globalnej i na dużą skalę".

Indeks gotowości inteligentnego przemysłu, wdrożony w 2019 r. („Indeks”), uważany jest za pierwsze na świecie narzędzie rozwoju Industry 4.0, umożliwiające kompleksową ocenę transformacji sektorów przemysłowych zarówno na poziomie przedsiębiorstw, jak i na poziomie krajowym. Na poziomie przedsiębiorstwa Indeks określa czterostopniowe podejście, aby pomóc firmom 
produkcyjnym zdobyć wiedzę o koncepcjach I4.0, ocenić obecny stan ich obiektów, opracować plan transformacji i zapewnić trwałą wartość dla ich firm. Na poziomie krajowym Indeks może potencjalnie służyć jako miernik do analizy porównawczej I4.0 w ramach różnych branż i między nimi, umożliwiając organom rządowym lepsze projektowanie interwencji politycznych dla poszczególnych sektorów w celu przyspieszenia ich transformacji. Indeks składa się z 3 bloków: proces, technologia i organizacja; każdy blok składa się z 8 filarów, które następnie odwzorowują 16 wymiarów oceny. Indeks zapewnia zbudowanie matrycy oceny, którą firmy mogą wykorzystać do monitorowania bieżących procesów, systemów i struktur wdrażania I4.0 (SIRI, 2019, s. 4-5). Macierz oceny służy również jako przewodnik do poprawy, doskonalenia krok po kro$\mathrm{ku}$ do poziomu rozwoju firmy w kierunku smart. Indeks stosowany jest już w Singapurze i sukcesywnie wdrażany jest w Indonezji, Tajlandii, Indiach, USA, Europie i Japonii. O ile syntetyczne wskaźniki przydatne są w prowadzeniu określonej strategii transformacji systemów produkcyjnych w przemyśle, o tyle wskaźniki o dużej szczegółowości, jak np. Automation Readiness Index, AI Readiness Index, Digitization Readiness Index, Information Society Readiness Index, Networked Readiness Index, których ilość nieustająco rośnie, mogą wywołać niejednoznaczne interpretacje obrazu całości zjawiska I4.0, którego istotą jest przecież złożoność i kompleksowość, dlatego wskaźniki szczegółowe warto stosować jako uzupełniające, nie zaś samoistnie oceniające.

Pozostając jednak w sferze argumentowania zasadności wdrażania I4.0, warto kontynuować przywoływanie liczb wskazujących na szanse i bariery transformacji przemysłu przez przedsiębiorstwa. I tak, samoocena przedsiębiorstw, co do ich przygotowania do rozwoju I4.0 wskazuje, że USA i Niemcy w 70\% były na to przygotowane w 2016 r., zaś Japonia tylko w 36\% (Ślusarczyk, 2018, s. 238). Jeśli chodzi o zastosowanie robotów w produkcji przemysłowej na świecie, to w samym 2018 r. ich instalacja wzrosła o 6\% do ponad 420 tys. sztuk, plan na 2022 r. to ponad 583 tys. sztuk, wzrost o 12\%; największym konsumentem robotów jest przemysł motoryzacyjny (30\%), dalej elektryczny/elektroniczny (25\%), metalowy i maszynowy (10\%); Azja jest największym rynkiem robotów, instaluje się tam ok. 67\% robotów (IFR, 2019, s. 13). Do pięciu głównych rynków robotów należą: Chiny - największy rynek, Japonia, USA, Korea Płd. i Niemcy; w Chinach instaluje się więcej robotów niż w Europie i USA razem. Niemcy, lider I4.0 w UE pod względem robotyzacji, plasowały się na miejscu piątym, planują jednak wzrost ich wykorzystania do 57\% przedsiębiorstw, w Polsce przedsiębiorstwa stosują/planują je w 26\% (IFR, 2019, s. 14). W UE wykorzystanie robotów przemysłowych i usługowych głównie odnotowuje się w dużych firmach, np. w 2018 r. przodowała Słowacja (32 roboty przemysłowe i 8 usługowych), dalej Bułgaria (30 robotów przemysłowych), Hiszpania (28 przemysłowych i 13 usługowych, Holandia (27 i 10), Chorwacja (25 przemysłowych i 16 usługowych) (Kuźniar, 2019, s. 64-65). Z kolei pozytywnie przedstawia się implementacja rozwiązań powiązanych z I4.0, takich jak na przykład integracja oprogramowania, gdzie Polska aktywizuje się na równi z Niemcami 65\% i 64\% (Przemysł 4.0 PL, 2015, s. 28). Do pracy z dużą ilością danych o znacznej objętości i złożoności najlepiej były przygotowane w 2018 r. przedsiębiorstwa takich krajów UE, jak: Malta (24\%), Holandia (22\%), Irlandia, Belgia (20\%), Finlandia (19\%), a Niemcy (15\%) (Kuźniar, 2019, s. 58). Na uwagę w tej kwestii zasługują też wyniki ankiety przeprowadzonej w 2016 roku przez PwC, w której wykazano nadzwyczajne możliwości osiągania korzyści dzięki transformacji przemysłu. Respondenci oczekują w 2020 roku podwojenia skali cyfryzacji, z 33\% w roku 2016 do $72 \%$ w roku 2020. Liderzy transformacji cyfrowej oczekują osiągnięcia prawie trzykrotnie większych sukcesów ekonomicznych; 10\% wszystkich badanych i 27\% liderów I4.0 oczekuje osiągnięcia w 2020 roku 30\% wzrostu przychodów i 30\% obniżkę kosztów oraz inwestycji w Przemyśle 4.0 na poziomie 5\% rocznych przychodów (PwC, 2016). USA i Niemcy oczekują ponad $90 \%$ wzrostu efektywności operacyjnej i ok. $80 \%$ wzrostu efektywności dzięki nowym modelom biznesowym I4.0, a także wzrostu konkurencyjności - USA 57\%, Niemcy 50\%, Japonia 54\%. Przezorność przedsiębiorców każe w pewnych przypadkach oczekiwać również obniżenia konkurencyjności, w największym stopniu ryzyka boją się Niemcy - 13\%, Japonia tylko 6\% (McKinsey Digital, 2016, s. 27). 4RP zmieni świat, ale tylko $14 \%$ zarządzających jest na nią gotowych - powiedział Punit Renjen, CEO Deloitte Global w Davos, cytując przeprowadzone przez firmę wyniki badania rynku (CNBC, 2018).

Zróżnicowane poziomy gotowości do I4.0 na świecie i w UE wyznaczają też inne zakresy wyzwań i zagrożeń dla przedsiębiorstw. W skali globalnej największe wyzwanie, a też trudności stanowią czynniki związane z digitalizacją, jej strukturą, kulturą i umiejętnościami cyfrowymi (58\%), kolejne miejsce zajmuje problem bezpieczeństwa danych i rozwiązań temu służących, co ogranicza też aktywność w zakresie analiz Big data (40\%), dalej ogromne potrzeby inwestycyjne (36\%), w Niemczech $41 \%$, w Polsce aż 46\%. W najlepszej sytuacji jest Japonia, jej przedsiębiorstwa takie potrzeby zgłaszają w $16 \%$, braki specjalistycznych kadr globalnie zgłaszane są w 25\%, ale w Niemczech aż w 43\% (PwC, 2016, s. 13-17; PwC, 2017, s. 34; Przemysł 4.0 PL, 2015, s. 7). Jednym z najtrudniejszych problemów, obok potrzeb inwestycyjnych jest z pewnością rodząca się sprzeczność między interesami przedsiębiorstwa a jego otoczeniem instytucjonalnym w zakresie kształtowania rynku pracy. Z jednej strony sukcesywnie zwiększa się liczba zadań, do których wykonywania ludzie nie są już konieczni, z drugiej rośnie potrzeba zatrudniania świetnie przygotowanych specjalistów w zawodach dotąd nieznanych. W 2015 roku Ed Gabrys, analityk firmy badawczej Gartner, na konferencji CEO Gartner twierdził, że do 2018 roku o 50\% spadnie zapotrzebowanie na pracowników obsługujących różne, tradycyjne procesy biznesowe, za to o 500\% wzrośnie zapotrzebowanie na kluczowych specjalistycznych pracowników w dziedzinie cyfrowego biznesu (Mejssner, 2015). Ta przepowiednia nie do końca się sprawdziła, jednak wciąż analizy wykazują, że w wyniku robotyzacji i automatyzacji pracy 
w ciągu kolejnych 10-20 lat może zniknąć 700 zawodów, bowiem zadecydują o tym znaczne w skali cechy sprzyjające zastępowaniu pracowników przez maszyny, takie jak: powtarzalność; zalgorytmizowany sposób postępowania, wykorzystanie siły fizycznej, zajęcia potencjalnie wysokourazowe, możliwość samoobsługi (Mejssner, 2015). Na rynku pracy ludzie będą rywalizować umiejętnościami z zawodowymi robotami, bo myślące maszyny, jak dowodzą badacze, są już teraz nieusuwalną częścią naszego życia (Walsh, 2018). Wiele organizacji, instytutów badawczych, uczelni oraz mediów tworzy listy zawodów zagrożonych przez postęp w dziedzinie automatyki i robotyzacji. Na liście BCC i Uniwersytetu Oksfordzkiego z 2014 roku do najbardziej zagrożonych zaliczono m.in. takie profesje, jak: sprzedawca telefoniczny (99\% szans na to, że roboty przejmą to stanowisko w ciągu najbliższych 20 lat); maszynistka od wprowadzania dyktowanego przez kogoś tekstu do komputera (98,5\%); sekretarka prawna $(97,6 \%)$; osoba sporządzająca sprawozdania finansowe (97,6\%); pracownik taśmy produkcyjnej (97,6\%). Za najmniej zagrożone zawody uznano: specjalistę do spraw zakwaterowania $(0,4 \%)$, celnika $(0,4 \%)$, doradcę zawodowego $(0,4 \%)$ oraz logopedę $(0,5 \%)$ (Mejssner, 2015).

Polskę uznaje się za jedno z państw należących do ścisłej czołówki pod względem podatności na automatyzację zadań wykonywanych w pracy. W perspektywie 20 lat na rynku pracy spadnie zapotrzebowanie przede wszystkim na robotników w przetwórstwie spożywczym, pracowników administracyjnych czy pracowników obrotu pieniężnego. Za szczególny przykład branży zagrożonej redukcjami zatrudnienia może służyć górnictwo, gdzie ze względu na relacje koszty - zyski niezbędna jest automatyzacja w celu podniesienia efektywności (Bitner i in., 2014, s. 18-20). Za państwa najmniej podatne na robotyzację pracy uznano kraje skandynawskie oraz kraje Beneluksu. W Norwegii i Szwajcarii odsetek miejsc pracy zagrożonych automatyzacją wynosi odpowiednio 17,5 i 18,7\%, za to dla Polski wynosi on aż $36,1 \%$. Tak niskie miejsce w rankingu sygnalizuje potencjalnie wysokie koszty społeczne procesów dostosowawczych w naszym kraju (Bitner i in., 2014, s. 18-20).

Oczywiście, nie można demonizować skutków nadchodzących zmian. Co prawda w krótkim okresie bezrobocie technologiczne wprowadza chaos w przedsiębiorstwach, ma negatywne skutki dla gospodarki i społeczeństwa, ponieważ oznacza niewykorzystany zasób zdolności i kompetencji ludzi, jednak w długim okresie zaczynają powstawać nowe, inne niż poprzednio miejsca pracy (Cowen, 2013) i niekoniecznie zmiany w procesach produkcji na skutek transformacji technologicznej spowodują destrukcję miejsc pracy szybszą niż ich kreacja. Technologia nie jest bowiem czymś pozaspołecznym, to nie sama technika i technologia pozbawia ludzi pracy, ale hybrydy, na które składają się aktorzy naukowi, laboratoria, system edukacji, państwo, rynek oraz interesy poszczególnych przedsiębiorstw, które stabilizują innowacje technologiczne (Afeltowicz, 2007, s. 123). W praktyce problem bezrobocia technologicznego wynika raczej z różnic w procesach dostosowawczych uzgadniania rozlicznych interesów i przemodelowania wskazanej hybrydy w średnim i dłu- gim okresie. W przedsiębiorstwie owe przemodelowania, z których wynika też gotowość do radykalnych przemian technologicznych (np. wdrożenia I4.0, cyfryzacji), rekomendowane są najczęściej w formułach poradnikowych (KPMG, 2017, s. 18). Zagadnienia te mają jednak znacznie głębsze uzasadnienie, co znajduje wyraz w cytowanej literaturze, a dotyczą kwestii zarządczych, społecznych, inwestycyjnych, które, choć wyrastają z mikroskali, operują $\mathrm{w}$ instytucjonalnym otoczeniu przedsiębiorstwa, nieustająco oddziałując na jego wewnętrzną aktywność.

I tak, do wiodących zadań w zakresie kwestii technologicznych należy zaliczyć: monitorowanie trendów technologicznych, cyfryzację, symulację i analitykę na wielkich zasobach liczb, synchronizację, koordynację, standaryzację, cyberbezpieczeństwo, samokontrolę systemów produkcyjnych i autonaprawę błędów. Wsparcie otoczenia to: wpływ na zmiany infrastrukturalne, zamówienia publiczne, wsparcie $\mathrm{B}+\mathrm{R}$, kompleksowa polityka innowacyjna, zapewnienie otwartego dostępu do wiedzy i informacji.

Świadomość technologiczna wyznaczać powinna przedsięwzięcia inwestycyjne, a tu priorytetem jest finansowanie I4.0 ze wszystkich dostępnych źródeł, co wiąże się z koniecznością stałego ich monitorowania, efektywne korzystanie z zasobów i wzrost efektywności inwestycji, zarządzanie finansami przy zastosowaniu adekwatnych technologii, koncentrowanie się na innowacjach finansowych, wielowymiarowa ocena ryzyka inwestycyjnego. $\mathrm{W}$ otoczeniu przedsiębiorstwo musi znaleźć wsparcie za pomocą specyficznych narzędzi i źródeł finansowania inwestycji I4.0 oraz działań z nim związanych, działalności informacyjnej upowszechniania wiedzy o źródłach oraz warunkach finansowania, a także współfinansowania innowacji technologicznych i społecznych towarzyszących I4.0, współdzielenie ryzyka finansowania inwestycji I4.0 (gwarancje państwa), narzędzia polityki fiskalnej i monetarnej.

W kwestii zarządzania dominować winno myślenie strategiczne na każdym poziomie, kultura innowacji, budowanie scenariuszy rozwoju, nawigacja technologiczna i produkcyjna, personalizacja procesów i produktów, angażowanie pracowników w podejmowanie decyzji, wykształcanie komórek B+R i zarządzanie innowacjami, $\mathrm{w}$ tym korzystanie $\mathrm{z}$ otwartej innowacji, narzędzia autonomiczne powiązane elementami łańcucha wartości, koncentacja na wartościach, nie na kosztach, elastyczne modele biznesowe, nowa logistyka, współpraca menedżersko-pracownicza, kumulacja talentów, elastyczność polityki kadrowej, kreacja nowych zawodów i nowych miejsc pracy, otwartość na nowe trendy (badania forsightowe), zabezpieczanie popytu na nowe role w zarządzaniu, formuły wynagrodzeń motywujących do przemian technologicznych. Wsparcie otoczenia powinno się materializować w tworzeniu warunków instytucjonalnych zastępowania pracy ludzkiej robotami czy współpracy człowiek - maszyna, wsparciu i szkoleniu zastosowania sztucznej inteligencji, instytucjonalizacji koordynacji czasu pracy w formułach zwiększających wydajność, strategii oraz warunków do projektowania i działania systemów „inteligentnych fabryk”, w nowym systemie badań, wdrożeń i szkoleń dla I4.0, dzieleniu ryzyka z tym związanego. 
Charakterystyczne dla kwestii społecznych (wyzwań i motywacji) jest to, iż pojawiają się one $\mathrm{w}$ otoczeniu przedsiębiorstwa, w nim się rozwijają i ponownie zasilają otoczenie firmy, skutkując pozytywnie bądź negatywnie na oba wymiary. Priorytetami w przedsiębiorstwie powinna być przede wszystkim integracja społeczna, współpraca, współtworzenie, wpływ na poziom życia, indywidualizacja motywacji, strategia wykorzystywania talentów i kompetencji, odczucie sprawiedliwości społecznej, eliminacja nierówności i dyskryminacji, klimat życzliwości i zaufania, identyfikacji z firmą. Zewnętrzne oddziaływanie na wskazane wyznaczniki mieści się w systemie edukacji - chodzi o wielopłaszczyznowe systemy edukacji i szkoleń, staży, emerytur itp., uczenie się zarządzania społeczeństwem, wzrost standardów socjalnych czy kumulowanie lokalizacyjne kreatywnej klasy (Florida, 2002). W szerszym wymiarze dotyczy to również polityki zdrowotnej, upowszechniania polityki państwa dobrobytu i społecznej gospodarki rynkowej, promocji gospodarki współdzielenia, tworzenia wielu platform uświadamiania i upowszechniania wiedzy, wyników badań, wdrażania innowacji społecznych oraz przygotowania ludzi do akceptacji ryzyka, łagodzenia oczekiwań społecznych co do drastycznych prób wypierania ludzi przez roboty, ochrony przed prekariatem, okresowych poszukiwań i kreowania pracy dla pracowników o niskich kwalifikacjach.

\section{Podsumowanie}

$\mathbf{P}$ rzemysł 4.0 stał się niejako strategią reindustrializacji Europy, wręcz formuła „ucieczki do przodu”, dlatego szczególnie po targach w Hanowerze w 2018 r. nastąpił dynamiczny rozwój europejskich inicjatyw na rzecz wspierania I4.0. Strategie, platformy lub specjalistyczne programy finansowe na rzecz rozwoju I4.0 posiadają już niemal wszystkie państwa najwyżej rozwinięte oraz duża część państw doganiających. Wielki entuzjazm dla jednego $\mathrm{z}$ wymiarów czwartej rewolucji przemysłowej, a więc I4.0 w wiodących gospodarkach europejskich (np. niemieckiej) nie tracą $\mathrm{z}$ pola widzenia konieczności pokonania wielu wyzwań, których nie da się zwalczyć bez aktywnej roli państwa.

Artykuł ma charakter merytorycznej refleksji, w przeciwieństwie do wielu publikacji o charakterze poradnikowym. Starano się w nim wykazać, na podstawie analizy prezentacji zawartych w naukowej literaturze przedmiotu, przeprowadzonych dotąd badań obcych i własnych, iż wdrożenie I4.0 to nie tylko kwestia nowych technologii i/lub narzędzi i/lub metod produkcji, w przedsiębiorstwie, ale implikuje ono zmiany we wszystkich aspektach zarządzania, a więc na poziomie wewnętrznym, w relacjach $\mathrm{z}$ partnerami i, bardziej ogólnie, $\mathrm{z}$ otoczeniem ( $\mathrm{z}$ jego głównymi aktorami państwem i rynkiem), w którym przedsiębiorstwo działa. Wskazuje się, iż wdrażanie I4.0 należy widzieć i badać w kontekście zrównoważonego rozwoju, w jego formule, potrójnego zrównoważenia. O ile bowiem dyskusji nie podlega specyficzne powiązanie I4.0 i zrównoważonego rozwoju, o tyle zainteresowania badawcze ukierunkowuje się przede wszystkim na filary ekonomiczne i filary środowiskowe, głównie technologiczne owych powiązań. Specjalnego wkładu badawczego wymaga w związku z tym zaniedbany dotąd w badaniach zrównoważonego rozwoju trzeci filar, społeczny, a tu szczególne zapotrzebowanie zgłaszane jest na innowacje społeczne oraz badanie i ocenę wzajemnych relacji pojawiających się między filarami potrójnie zrównoważonego rozwoju w kontekście I4.0.

Proponowane $\mathrm{w}$ artykule podejście refleksyjne powinno zasugerować menedżerom, iż holistyczny sposób starannego sformułowania strategii i mapy drogowej przejścia do Przemysłu 4.0 jest jedynym, pozwalającym na pełne skorzystanie $\mathrm{z}$ całego pakietu pozytywnych wyznaczników tej koncepcji, które wydaje się ona przynosić zainteresowanym. Oczywiście, prezentowany materiał, mimo iż z pewnością zawiera pewne wskazania uświadamiające zjawisko i konsekwencje pomocne w akceptacji wdrażania Przemysłu 4.0 przez menedżerów, nie oznacza wypełnienia luk badawczych przedmiotu, wręcz przeciwnie, monituje się konieczność podejmowania ciągłych, a także pogłębionych studiów umożliwiających stworzenie lepszej bazy merytorycznego wsparcia dla zarządzających zarówno przedsiębiorstwem, jak i jego otoczeniem.

\section{prof. dr hab. Elżbieta Mączyńska Szkoła Główna Handlowa w Warszawie Kolegium Nauk o Przedsiębiorstwie ORCID: 0000-0002-4624-4268 e-mail: ela4@wp.pl}

\section{prof. dr hab. Ewa Okoń-Horodyńska Uniwersytet Jagielloński \\ Wydział Zarządzania i Komunikacji Społecznej ORCID: 0000-0002-2548-254X e-mail: ewa.okon-horodynska@uj.edu.pl}

\section{Przypisy}

1) W tekście tym prezentacje statystyczne ograniczone zostały do niezbędnego minimum, po pierwsze ze względu na ich obfitość w literaturze przedmiotu, po drugie ze względu na ich ograniczoną i nietrwałą aktualność w miarę upływu czasu oraz po trzecie, najważniejsze, ze względu na skoncentrowanie się na jakościowym, a nie ilościowym wymiarze analizowanych tu problemów.

2) Wyniki realizowanego w SGH cyklu badań nt. konsekwencji barier $\mathrm{w}$ otoczeniu instytucjonalnym przedsiębiorstw oraz wyniki badań UJ prowadzonych w ramach międzynarodowego konsorcjum w projekcie: Industrie 4.0 zwischen Idee und Realitaet (Banse i in., 2019).

3) Dobrym przykładem jest tu inicjatywa SETI@Home pokazująca znaczenie mocy obliczeniowej dla kształtowania warunków instytucjonalnych, zob. Benkler (2008, s. 97-98).

4) Badania wykazują, że w 2018 r. wg głównych baz danych publikacji naukowych opublikowano prawie 10000 prac z kluczem „Industry 4.0”, $1345 \mathrm{z}$ kluczem „business and management”, 495 z kluczem „zarządzanie”, ale ostatecznie, po wyłączeniu duplikatów i abstraktów pozostało 68 publikacji ściśle dotyczących 
zarządzania w warunkach I4.0. Stąd też badanie przedmiotu cechuje wiele poważnych luk odnoszących się do skali i rodzaju zmian w zarządzaniu, jak komunikacja z partnerami, identyfikowanie aktorów ecosystemu I4.0, w którym operują firmy, zmieniających się struktur zarządzania w związku z otwartą innowacją itp. (Sustainability, 2018, s. 4-6).

\section{Bibliografia}

[1] ACATECH (2016), Industrie 4.0 - International Benchmark, Options for the Future and Recommendations for Manufacturing Research (INBENZHAP), National Academy of Science and Engineering, https://en.acatech.de/project/ industrie-4-0-international-benchmark-options-for-the-future-and-recommendations-for-manufacturing-research-inbenzhap/, access date: 18.12.2019.

[2] Afeltowicz Ł. (2007), Czy technika pozbawia nas pracy? Bezrobocie technologiczne w perspektywie teorii aktora-sieci, „Studia Socjologiczne”, Nr 1(184), s. 108-126.

[3] Akerlof G.A., Shiller R.J. (2017), Złowić frajera. Ekonomia manipulacji i oszustwa, PTE, Warszawa.

[4] Banse G., Thelen J., Lingner S. (eds.), (2019), Industrie 4.0 zwichen Idee und Realität, Ein Ländervergleich. Abhandlungen der Leibniz-Sozietät der Wissenschaften, Band 54, Trafo Verlag, Berlin.

[5] Benkler Y. (2008), Bogactwo sieci. Jak produkcja społeczna zmienia rynki i wolność, Wydawnictwa Akademickie i Profesjonalne, Warszawa.

[6] Berger R. (2014), Industry 4.0 - The New Industrial Revolution. How Europe Will Succeed, RB GmbH, München.

[7] Bitkom (2016), Digitalisierung in der Landwirtschaft, https://www.bitkom.org/sites/default/files/file/import/ Bitkom-Pressekonferenz-Digitalisierung-in-der-Landwirtschaft-02-11-2016-Praesentation.pdf, access date: 22.12.2019.

[8] Bitner M., Starościk R., Szczerba P. (2014), Czy robot zabierze ci prace? Sektorowa analiza komputeryzacji i robotyzacji europejskich rynków pracy, „Working Paper”, Nr 1, WISE, Warszawa, http://wise-europa.eu/wp-content/ uploads/2016/03/PolicyWorking-WISE-_nr1_141029.pdf, data dostępu: 12.11.2019 r.

[9] Boston Consulting Group (2016), Industry 4.0: The Future of Productivity and Growth in Manufacturing Industries, https://www.zvw.de/media.media.72e472fb-1698-4a158858-344351c8902f.original.pdf, access date: 21.12.2019.

[10] Buhr D., Stehnken T. (2018), Industry 4.0 and European Innovation Policy. Big Plans, Small Steps, Wiso Discurs, No. 12, Friedrich Ebrt Stiftung.

[11] CEU (2018), Council of the European Union, COMPETE 590, Brussels, 14 September, https://www.consilium.europa. eu/media/36515/rethinking-eu-indsutry_ai-and-robotics. pdf, access date: 5.04.2019.

[12] CNBC (2018), CNBC Interview with Deloitte CEO, Punit Renjen, from the World Economic Forum, Davos, 24 Jan. 2018.

[13] Cowen T. (2013), Average is Over: Powering America Beyond the Age of the Great Stagnation, Dutton.

[14] CRN (2016), Kto ma prawo do Open Source? https://www. crn.pl/aktualnosci/kto-ma-prawo-do-open-source, data dostępu: 15.12.2019 r.
[15] DESI (2019), The Digital Economy and Society Index, EC, https://ec.europa.eu/digital-single-market/en/desi, access date: 12.01.2020.

[16] DII4.0 (2017), Faarup J., Faarup A., Global Industry 4.0 Readiness Report 2016, Danish Institute of Industry 4.0, Copenhagen, January (dok.elektr.www.DII4.dk/readiness).

[17] EDB (2017), Launch of the Singapore Smart Industry Readiness Index, Economic Department Board, https://www. edb.gov.sg/en/news-and-events/news/launch-of-singapore-smart-industry-readiness-index.html, access date: 28.12.2019.

[18] Edvinsson L., Malone M.S. (2001), Kapitat intelektualny, Wyd. Naukowe PWN, Warszawa.

[19] EFFRA (2018), ConnectedFactories, European Factories of the Future Research Association, Brussels, https://www.effra. eu/connectedfactories, access date: 12.04.2018.

[20] Eurostat (2019), Key Figure for Europe. Digital Society, https://ec.europa.eu/eurostat/cache/digpub/keyfigures/, access date: 15.01.2020.

[21] Florida R. (2002), The Rise of Creative Class, Basic Books, New York.

[22] GUS (2019), Społeczeństwo informacyjne w Polsce. Wyniki badań statystycznych z lat 2015-2019, Warszawa - Szczecin.

[23] IDI (2019), The ICT Development Index. Methodology, indicators and definitions, ITU, https://www.itu.int/en/ITU-D/ Statistics/Documents/statistics/ITU_ICT\%20Development\%20Index.pdf, access date: 22.01.2020.

[24] IFR (2019), Executive Summary World Robotics 2019 Industrial Robots, https://ifr.org/downloads/press2018/Executive\%20Summary\%20WR\%202019\%20Industrial\%20 Robots.pdf, access date: 12.01.2020.

[25] IMPULS (2015), Lindner T., Wittenstein M., Gernandt J., Röger S., Industrie 4.0 - Readiness, IMPULS-Stiftung, Aachen, Köln, Oktober.

[26] ITU (2017), ICT Development Index 2017, ITU Data, https://www.itu.int/net4/ITU-D/idi/2017/index.html, access date: 12.01 .2020 .

[27] ITU (2018), Measuring the Information Society Report, ITU Publications, https://www.itu.int/dms_pub/itu-d/opb/ind/DIND-ICTOI-2018-SUM-PDF-E.pdf, access date: 11.12.2019.

[28] Kelly K. (2018), NIEUNIKNIONE. Jak inteligentne technologie zmienia nasza przyszłość, tłum. P. Cypryański, Poltext, Warszawa.

[29] KE (2018), EU Industry Day 2018 - day 1, Brussels, 22.02., s. 1-4, https://ec.europa.eu/info/events/eu-industry-day/ 2018-day-1_pl, access date: 3.04.2018.

[30] Kleer J. (2016), Cywilizacje i ich przesilenia, „Studia Ekonomiczne INE PAN", Nr 1, s. 1-4.

[31] Kołodko G.W. (2014), Nowy pragmatyzm, czyli ekonomia i polityka dla przyszłości, „Ekonomista”, Nr 2, s. 161-180.

[32] Kołodko G.W. (2010), (red.), Globalizacja, kryzys i co dalej? Poltext, Warszawa.

[33] Kowalski A., Weresa M. (red.), (2019), Raport o konkurencyjności 2019, SGH, Warszawa.

[34] KPMG (2017), Beyond the Hype: Separating Ambition from Reality in Industry 4.0, Reported by D. Gates \& M. Bremicker, s. 1-24, https://assets.kpmg/content/dam/kpmg/uk/ pdf/2017/06/Industry-4.0-beyond-the-hype.pdf, access date: 17.12.2019. 
[35] Kuźniar A. (2019), Czwarta rewolucja przemysłowa i jej skutki dla gospodarki światowej, [w:] A. Kowalski, M. Weresa (red.), Raport o konkurencyjności 2019, SGH, Warszawa, s. $49-71$.

[36] Lasi H., Fettke P., Kemper H.G., Feld T., Hoffman M. (2014), Industry 4.0, „Business \& Information Systems Engineering", No. 6(4), pp. 239-242.

[37] Lassalle F. (1862), Das Arbeiter-Programm. Über den besonderen Zusammenhang der gegenwärtigen Geschichtsperiode mit der Idee des Arbeiterstandes, 12. April, access date: 23.03.2019.

[38] Lu Y. (2017), Industry 4.0: A Survey on Technologies, Applications and Open Research Issues, „Journal of Industrial Information Integration”, No. 6(4), pp. 239-242.

[39] Mazzucato M. (2016), Przedsiębiorcze państwo, Heterodox, Warszawa.

[40] Markowski K. (1992), Rola państwa w gospodarce rynkowej, PWE, Warszawa.

[41] Mączyńska E. (2017), Rola państwa w gospodarce - kontrowersje i ich podłoże, [w:] S. Owsiak (red.), Państwo a gospodarka, PTE, Warszawa, s. 30-44.

[42] McKinsey Digital (2016), Industry 4.0 after the Initial Hype. Where Manufacturers are Finding Value and How They Can Best Capture It.

[43] Mejssner B. (2015), Komu grozi bezrobocie technologiczne, https://www.computerworld.pl/news/Komu-grozi-technolo giczne-bezrobocie,403361.html, data dostępu: 21.02.2016 r.

[44] Micklethwait J., Wooldridge A. (2000), Szamani zarządzania, Wydawnictwo Zysk i S-ka, Poznań.

[45] Okoń-Horodyńska E. (2018), Przemysł 4.0 - technologiczne bezpieczeństwo UE? [w:] J. Kleer, K. Prandecki (red.), Bezpieczeństwo Europy w globalnym świecie, Polska Akademia Nauk, Komitet Prognoz Polska 2000 Plus przy Prezydium PAN, Warszawa, s. 207-240.

[46] Olender-Skorek M. (2017), Czwarta rewolucja przemysłowa a wybrane aspekty teorii ekonomii, „Nierówności Społeczne a Wzrost Gospodarczy", Nr 5(3), s. 38-49.

[47] Olszewski M. (2016), Mechatronizacja produktu i produkcji - przemyst 4.0, „Pomiary Automatyka Robotyka”, Nr 3, s. 13-28, DOI: 10.14313/PAR_221/13.

[48] Owsiak S. (2017), Państwo a gospodarka, PTE, Warszawa.

[49] Peters R. (2010), Internet Oekonomie, Springer, Dortrecht-London-New York.

[50] Postman N. (1992), Technopoly. The Surrender of Culture to Technology, Knopf, New York.

[51] Przemysł 4.0 PL(2015), Szansa czy zagrożenie dla rozwoju innowacyjnej gospodarki? BCG, Warszawa, http://docplayer. pl/24443942-Przemysl-4-0-pl-szansa-czy-zagrozenie-dla-rozwoju-innowacyjnej-gospodarki.html, data dostępu: 17.11.2019 r.

[52] PwC (2016), Industry 4.0: Building the Digital Enterprise. 2016 Global Industry 4.0 Survey, https://www.pwc.com/ gx/en/industries/industries-4.0/landing-page/industry-4. 0-building-your-digital-enterprise-april-2016.pdf, access date: 17.11.2019.

[53] PwC (2017), Przemysł 4.0, czyli wyzwania współczesnej produkcji, https://www.pwc.pl/pl/publikacje/2017/przemysl -4-0.html, data dostępu: 18.11.2019 r.

[54] Reagan R. (2012), Przemówienie inauguracyjne, „Rząd nie jest lekarstwem $z$ tej prostej przyczyny, że to on stanowi problem", http://wpolityce.pl/polityka/125769-ronald-reagan-prze mowienie-inauguracyjne-rzad-nie-jest-lekarstwem-z-tej-prostej-przyczyny-ze-to-on-stanowi-problem, data dostępu: $5.04 .2019 \mathrm{r}$

[55] Rifkin J. (2011), The Third Industrial Revolution. How Lateral Power is Transforming Energy, the Economy, and the World, St Martin's Press, New York.

[56] Schumpeter J.A. (2009), Kapitalizm, socjalizm, demokracja, Wydawnictwo Naukowe PWN, Warszawa.

[57] Schwab K. (2015), The Forth Industrial Revolution. What It Means and How to Respond, Foreign Affairs, December, www.foreignaffairs.com.

[58] SIRI (2019), Manufacturing Tranformation. Insight Report, EDB, Singapore.

[59] Smith A. (1989), Teoria uczuć moralnych, tłum. D. Petsch, PWN, Warszawa.

[60] Summers L.H. (2014), Reflections on the 'New Secular Stagnation Hypothesis', [in:] C. Teulings, R. Baldwin (eds.), Secular Stagnation: Facts, Causes and Cures, Centre for Economic Policy Research (CEPR), London, pp. 27-41.

[61] Sustainability (2018), Piccarozzi M., Aquilani B., Gatti C. (eds.), Industry 4.0 in Management Studies: A Systematic Literature Review, No. 10(10), 3821, DOI: 10.3390/ su10103821.

[62] Ślusarczyk B. (2018), Are We are Ready? „Polish Journal of Management Studies", Vol. 17, No. 1, pp. 232-248.

[63] Wallerstein I., Randall C., Michael M., Derluguian G., Calhoun C. (2016), Czy kapitalizm ma przyszłość, Wydawnictwo Akademickie Dialog, Warszawa.

[64] Walsh T. (2018), To żyje. Sztuczna inteligencja: od logicznego fortepianu po zabójcze umysty, Wyd. Naukowe PWN, Warszawa.

[65] Wojtyna A. (1997), Przyszłość państwa a gospodarka, Komitet Prognoz „Polska w XXI wieku” przy Prezydium PAN, Warszawa.

[66] World Economic Forum (2018), Readiness for the Future of Production Report 2018, http://wef.ch/fopreadiness18, access date: 22.11.2018.

\section{The Company and its Environment in the Face of the Fourth Industrial Revolution - Challenges, Opportunities and Threats}

\section{Summary}

The article has the nature of substantive reflection. The authors have attempted to show in it, based on the analysis of presentations contained in Polish and foreign literature of the subject, foreign and own research carried out so far that the implementation of Industry 4.0 is not only a matter of new technologies and / or tools and / or production methods in the enterprise, but it implies changes in all aspects of the company's operation, not only at the internal level, but also in relations with partners and, more generally, with the environment (with its main actors - the state and the market). The analytical goal here is to indicate that the exceptionally fast pace of new technologies emergence makes it impossible for producers, consumers and regulatory mechanisms 
to prepare beforehand to changes resulting from them, and what follows to identify the necessary directions of modifying the enterprise management and the functioning of the institutional environment which create new opportunities but also barriers and even threats. The authors put forward the thesis that opening the economy to the potential of the fourth industrial revolution is becoming an indispensable condition for maintaining the ability to compete in the market and to meet new, yet consistently efficiency-oriented market requirements, forcing a change in the business philosophy, which temporarily leads to various asymmetries and socio-economic maladjustments, management and regulatory issues. Therefore, the point is to involve enterprises into alleviating these asymmetries and achieve the goal of triple sustainable inclusive development, to learn how to reconcile social, economic, technological and ecological goals in the management process, while minimising the waste of material and human resources. The assessments and conclusions contained in the study are largely based on hermeneutics. Three threads are signalled in the study, the first refers to the theoretical foundations of the framework of the enterprise environment shaped by state-market relations and the necessity of its evolution in new technological and social conditions; the second concerns the basic condition of 4RP dynamism, which is digitisation and the adequacy of its progress to challenges, while the third thread discusses and assesses the readiness to implement Industry 4.0.

\section{Keywords}

fourth industrial revolution, Industry 4.0, the state-market relations, institutional environment 